\title{
The Role Of Melatonin In Aluminium Induced Genotoxicity In Female Albino Rats
}

\author{
Zeinab E. Hanafy \\ Department of Zoology, Faculty of Science (Girls), Al-Azhar University.
}

\begin{abstract}
Aim of the work, In spite of the wide range of use of aluminium. With the increasing awareness of possible health hazards associated with their use, more attention have been focused on their biological and biochemical activity. Aluminium salts are used as the active antiperspirant in under cosmetics, but the effects of widespread, long term and increasing use remain unknown. Aluminium is known to have genotoxic profile, capable of causing both DNA alterations and epigenetic effects. Melatonin reduces the free radical generation and metal detoxification. This study was planned to determine the effects of melatonin on aluminium induced toxicity in the chromosomes of bone marrow cell .

Material and Methods, Forty female albino rats were used in the present work for the chromosomal analysis. Four groups of adult female albino rats were used in the following way: Group -I, control group; Group-II,50 mg / kg b.wt aluminium orally; Group-III, $50 \mu \mathrm{g} / \mathrm{kg}$ b.wt melatonin orally and Group- IV, $50 \mathrm{mg} / \mathrm{kg}$ b.wt aluminium orally (am) $+50 \mu \mathrm{g} / \mathrm{kg} \mathrm{b}$.wt melatonin orally(pm). Doses were given 30 days. All animals were sacrificed and the bone marrow of femur bones was taken for subsequent cytogenetic studies.

The results, Aluminium treatment induced a significant increase in the structural as well as numerical chromosomal aberrations. The frequency of chromosomal aberrations showed significant decrease when rats treated with melatonin and aluminium .In conclusion, the results indicated that melatonin showed a significant improvement of genetic damages induced by aluminium.
\end{abstract}

\section{Introduction}

Numerous environmental and industrial are capable of causing cytogenetic damage in experimental animal and human [Heddle et al., 1983]. Aluminium ( Al ) chloride $(10-200 \mu \mathrm{M})$ increased the aluminium content in hepatocytes isolated from fed male rats in a time -and concentration - dependent manner . After $60 \mathrm{~min}$ of incubation with $100 \mu \mathrm{M}$ aluminium about $45 \%$ of cellular aluminium was found each in the mitochondrial and the post mitochondrial fraction of hepatocytes, whereas about $5 \%$ of aluminium sedimented with nuclei and cell debris. [ Muller and Wilhelm 1987]. Aluminium linked inhibition of several enzymes, such as ATP ase, hexokinase, phosphofructokinase, and lactate dehydrogenase ( LDH ) in brain fractions [Riedel and Christensen 1979: Bock and Ash 1980 ; Lai and Blass, 1984 and Ganrot, 1986].

Aluminium is known to react with targets within the cell similar to those of known toxic metals , such as cadmium [Nieboer and Richardson 1980 and Muller and Wilhelm 1987 ].

Melatonin is the principal secretary product of the pineal gland. The molecule endocrine actions on other glands, but it also has been shown to function as a free radical scavenger, antioxidant and in immunomodulation [Conti and Maestroni 1995 ; Reiter et al.,1995 and Vijayalaxmi et al., 2004]. Melatonin is highly lipid soluble and enters cells and subcellular compartments with ease [Reiter 1991] ; melatonin has not been shown to be toxic . Melatonin and its precursors, tryptophan and serotonin, were examined for their metal binding affinities for both essential and toxic metals : aluminium, cadmium , copper, iron, lead and zinc [ Limson et al., 1998 ] .

Melatonin, together with other free radical scavenger in the brain, reduces the 
free radical damage caused by aluminium .Since melatonin is produced by the pineal gland only in the dark, the excess of electric light in developed countries may help explain why Alzheimer s disease (AD) is more prevalent in these countries than in rural Africa [Van - Rensburg et al ., 1997; Limson et al., 1998; Lack et al ., 2001 and Maharaj et al. 2005]

Melatonin is consider a biologicalresponse modifier of the immune system with broad application in veterinary medicine. Melatonin enhances a defined immune response in vivo opens new perspectives for the improvement of th2biased immune response by alum adjuvants [ Regodon et al., 2005 ].

The administration of melatonin caused a decrease in the frequency of chromosome aberration in irradiated animal [Badr et al., 1999] . Also melatonin decrease the frequency of chromosome aberration and DNA concentration in the diabetic animal [Hanafy 2005]. Theirfore, the present study was designed to determine the effects of melatonin on aluminium- induced toxicity on the chromosomes in female albino rats.

\section{Material and Methods}

\section{Material:}

Aluminium hydroxide ( $\mathrm{ALOH})$ was supplied by Sigma Chemical Co., USA; while melatonin was obtained from Amoun. Ltd. Co. Egypt.

Animals:

Forty female albino rats approximately 160 - 200 gm of weight were used for this study.

The rats were divided into four group:

Group -I: control group, administered distilled water by stomach tube.

Group -II: Aluminium hydroxide ( ALOH) was dissolved in distilled water and given in dose of $50 \mathrm{mg} / \mathrm{kg}$ b.wt. orally by stomach tube.

Group -III: melatonin was dissolved in distilled water (1:500) and given in dose of $50 \mu \mathrm{g} / \mathrm{kg}$ b.wt. orally by stomach tube .

Group - IV: female rats was given $50 \mathrm{mg}$ $/ \mathrm{kg}$ b.wt aluminium ( am ) and $50 \mu \mathrm{g}$
$/ \mathrm{kg} \mathrm{b}$.wt of melatonin ( $\mathrm{pm}$ ).

Doses were given 30 days orally by stomach. All animals were sacrificed and the bone marrow of femur bones was taken for subsequent cytogenetic studies

\section{Assays to detect chromosomal aberra- tions :}

The bone marrow tissue was subjected to colchicines treatment $(0.5$ solution $0.1 \mathrm{ml} /$ culture), hypotonic treatment ( $\mathrm{KCI}, 5.6 \mathrm{~g} / \mathrm{l}$ ), fixed in acetomethanol, spread, and stained by Giemsa stain, in 6.8 phosphate buffer [ Evans,1987 ].

To analyze the frequency and type of chromosomal aberrations, 100 well spread metaphases were analyzed under the microscope for each rat in either the therapeutic or double therapeutic dose-exposed animals. The chromosomal aberrations observed were classified as follows: Structural chromosomal aberrations which include gap, break, deletion and centromeric attenuation and numerical chromosomal aberrations which include endomytosis and polyploidy.

\section{Statistical Analysis:}

Analysis was preformed using the Statistical Package for Social Sciences (SPSS, Version 10).

Medians were compared using the Kruskal wallis H-test (non-parametric ANOVA) followed by Q-test to show the difference between individual groups. PValue less than 0.05 was considered significant [Kruskal and Wallis,1952].

\section{Results:}

\section{Structural chromosomal aberrations}

In bone marrow cells of rats of melatonin group (group III ), no significant difference was observed as regards structural chromosomal aberrations when compared with the control group (Table 1).

However, the mean percentage of both the individual and total structural chromosomal aberrations showed significant increases in aluminium group (20\%) when compared with the control groups (1\%) (Table 1).

On the other hand, rats treated simultaneously with aluminium + melatonin (group IV) showed highly significant 
decrease of the total structural chromosomal aberrations $(11 \%)$ in comparison is with aluminium- treated rats (20\%), however, the mean percentage of the total structural chromosomal aberrations was significantly in group IV than the corresponding values of the control groups ( Table 1, Fig. 1 ).

\section{Numerical chromosomal aberrations}

In the melatonin group, no significant differences were observed when compared with the control groups as regards the numerical chromosomal aberrations (Table $1)$.
Meanwhile, the frequency of the total numerical chromosomal aberrations was a significant increased in aluminium - treated rats $(7 \%)$ when compared with the control groups $(1 \%)$ (Table 1$)$.

Rats treated with aluminium + melatonin (group IV) showed a significant decrease of total numerical chromosomal aberrations ( $5 \%$ via $7 \%$ in aluminium treated only ). However, the mean percentage of the total numerical chromosomal aberrations was significantly higher in group IV than the corresponding values of the control groups (Table 1, Fig. 2 ).

Table (1): Chromosomal aberrations in the different studied experimental groups.

\begin{tabular}{|c|c|c|c|c|c|c|c|c|}
\hline \multirow{2}{*}{$\begin{array}{l}\text { Experimental } \\
\text { groups }\end{array}$} & \multicolumn{8}{|c|}{ Chromosomal aberrations } \\
\hline & Gap & Break & Deletion & $\begin{array}{l}\text { Centromere } \\
\text { attenuation }\end{array}$ & total & ploidy & endomytosis & total \\
\hline Control & $\begin{array}{c}0 \mathrm{a} \\
(0-1)\end{array}$ & $\begin{array}{c}0 \mathrm{a} \\
(0-0)\end{array}$ & $\begin{array}{c}0 \mathrm{a} \\
(0-1)\end{array}$ & $\begin{array}{c}1 \mathrm{a} \\
(0-1)\end{array}$ & $\begin{array}{c}1 \mathrm{a} \\
(0-2)\end{array}$ & $\begin{array}{c}1 \mathrm{a} \\
(0-2)\end{array}$ & $\begin{array}{c}1 \mathrm{a} \\
(0-1)\end{array}$ & $\begin{array}{c}1 \mathrm{a} \\
(1-3)\end{array}$ \\
\hline Aluminium & $\begin{array}{c}5 \mathrm{~b} \\
(4-5)\end{array}$ & $\begin{array}{c}7 \mathrm{c} \\
(6-7)\end{array}$ & $\begin{array}{c}4 c \\
(3-5)\end{array}$ & $\begin{array}{c}4 c \\
(3-5)\end{array}$ & $\begin{array}{c}20 \mathrm{~d} \\
(19-21)\end{array}$ & $\begin{array}{c}4 c \\
(3-5)\end{array}$ & $\begin{array}{l}3 c \\
(2-4)\end{array}$ & $\begin{array}{c}7 \mathrm{c} \\
(5-8)\end{array}$ \\
\hline Melatonin & $\begin{array}{c}1 \mathrm{a} \\
(0-2)\end{array}$ & $\begin{array}{c}2 \mathrm{~b} \\
(2-3)\end{array}$ & $\begin{array}{c}2 \mathrm{~b} \\
(1-3)\end{array}$ & $\begin{array}{c}0 \mathrm{a} \\
(0-0)\end{array}$ & $\begin{array}{c}5 \mathrm{~b} \\
(4-6)\end{array}$ & $\begin{array}{c}1 \mathrm{a} \\
(0-1)\end{array}$ & $\begin{array}{c}1 \mathrm{ab} \\
(0-3)\end{array}$ & $\begin{array}{c}1 \mathrm{a} \\
(1-3)\end{array}$ \\
\hline $\begin{array}{c}\text { Aluminium + } \\
\text { Melatonin }\end{array}$ & $\begin{array}{c}3 \mathrm{~b} \\
(3-4) \\
\end{array}$ & $\begin{array}{c}3 \mathrm{~b} \\
(3-4)\end{array}$ & $\begin{array}{c}2 \mathrm{~b} \\
(2-4)\end{array}$ & $\begin{array}{c}2 \mathrm{~b} \\
(1-3)\end{array}$ & $\begin{array}{c}11 \mathrm{c} \\
(10-12)\end{array}$ & $\begin{array}{c}2 \mathrm{~b} \\
(1-3)\end{array}$ & $\begin{array}{c}2 \mathrm{~b} \\
(2-3)\end{array}$ & $\begin{array}{c}5 \mathrm{~b} \\
(3-6)\end{array}$ \\
\hline Chi-square & 17.14 & 17.82 & 15.48 & 16.88 & 18.02 & 13.81 & 12.18 & 15.857 \\
\hline p-value & 0.0006 & 0.0004 & 0.001 & 0.0007 & 0.0004 & 0.003 & 0.006 & 0.001 \\
\hline
\end{tabular}

Data are expressed as median and range of five readings (out of 100 metaphase spreads) in each experiment. The different letters indicate statistically significant median values according to Kruskal Waalis H-test (non-parametric ANOVA)
a : non significant
$\mathrm{b}$ : significant
c : significant
d : highly significant 


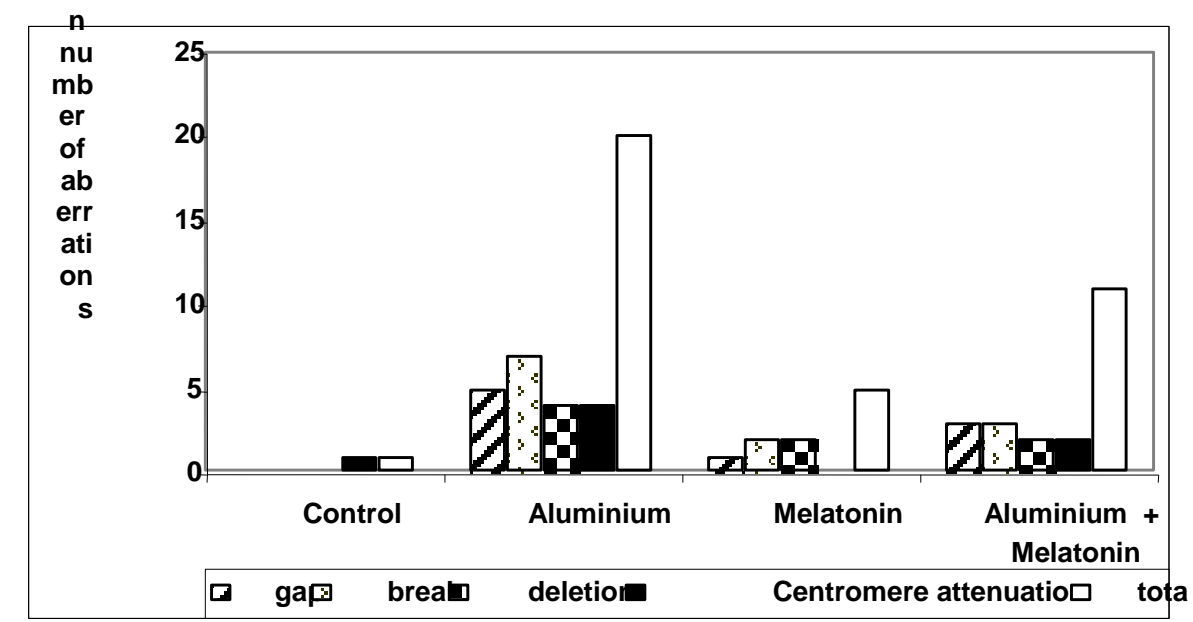

Fig. (1): Median number of chromosomal aberrations (gap, break, deletion, centromere attenuation and total) in the metaphase spreads taken from female albino rats of the different experimental groups

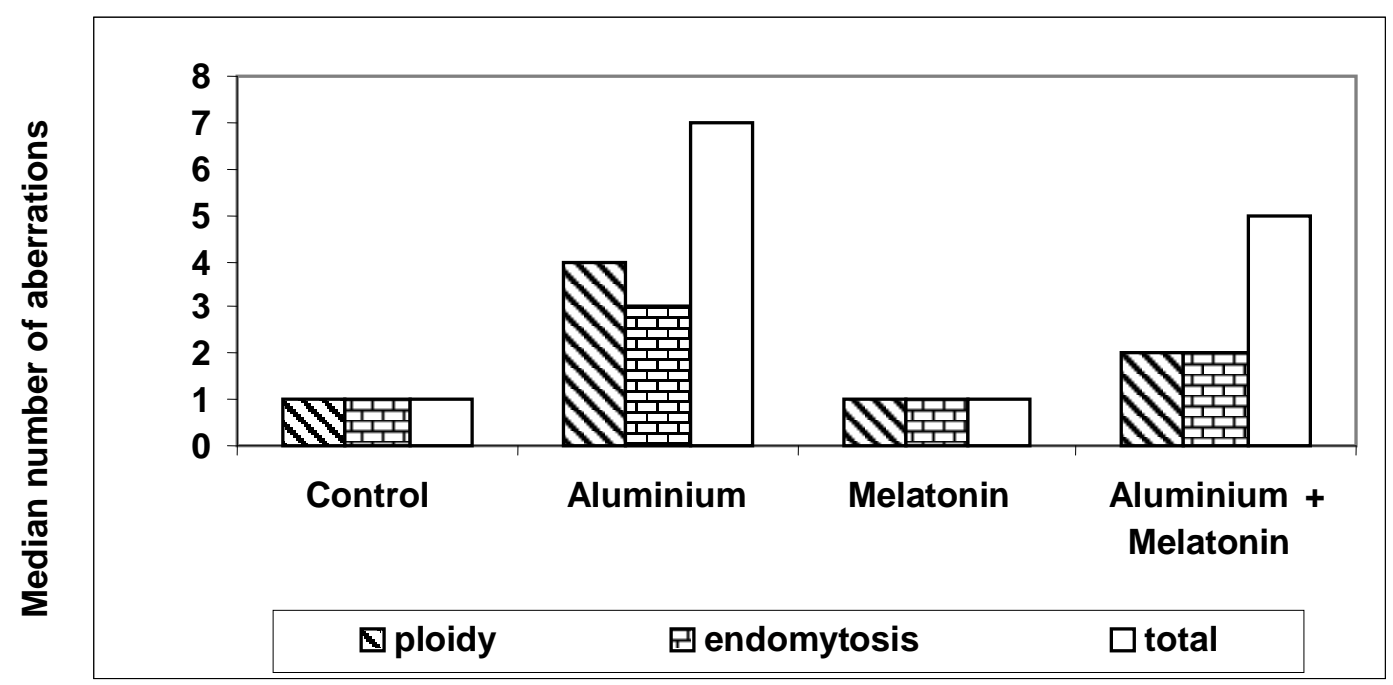

Fig. (2): Median number of chromosomal aberrations (ploidy, endomytosis and total) in the metaphase spreads taken from female albino rats of the different experimental groups

\section{Discussion}

The results of the present study clearly showed that aluminium is a genotoxic agent. This was evidenced by the increased incidence of chromosomal aberration particularly gaps and break in aluminium treated rats.

The importance of recording gaps in assessing the genotoxic effects of compound is controversial. Some authors considered gaps to be a sensitive indicator of chemically induced chromosomal damage, while others considered the scoring of gaps to be highly subjective and therefore an unsuitable indicator of genotoxicity [Hassan,1997]. However, since some gaps could be deletions, it is appropriate to analyze the data including and excluding gaps [Preston et al., 1987]. In the present study, aluminium gave a highly significant increase in the number of aberrant cells, even after excluding gaps.

Aluminium induced genotoxicity is 


\section{Zeinab E.Hanafy}

usually considered to involve free radicals, while melatonin reduced this effect - [Menendez - Pelaez and Reiter 1993 and Van -Rensburg et al., 1997 ] .

Aluminium caused lipid peroxidiation in the presence of iron(ll) ion( $\mathrm{Pe} 2+)$. Hydrogen peroxide (H2O2) greatly exacerbated the toxicity of aluminium. $\mathrm{H} 2 \mathrm{O} 2$ induced chromosomal aberration. Melatonin prevented lipid peroxidation by aluminium in the absence of $\mathrm{H} 2 \mathrm{O} 2$, but only reduced the process when $\mathrm{H} 2 \mathrm{O} 2$ was present. .[ Van - Rensburg et al ., 1997 and De-Selvia et al.,1999 ]

Millan-Plano et al., (2003) suggest that the indoleamine melatonin may potentially act as neuroprotectant agents in the therapy of those diseases with elevated aluminium concentrations in the tissues.

This study revealed that in bone marrow cell, no significant chromosomal aberration was observed in animals treated with melatonin only. While melatonin produced a significant decrease of the total structural chromosomal aberration at a percentage of $11 \%$ via $20 \%$ in animals treated with aluminium only and the numerical chromosomal aberration showed a decrease at a percentage of $5 \%$ via $7 \%$ in animals treated with aluminium only . The present results were in agreement with Sewerynek et al., 1996 and Vijayalaxmi et al. ( 1998 ) showed that melatonin ingestion exhibited a significantly decreased extent of primary DNA damage and reduced frequencies of chromosomal aberration and micronuclei.

Also Badr et al . ( 1999 ) found that no mutagenic effect of melatonin on chromosomal aberration frequency in spermatogonial chromosomes. Administration of one single dose of melatonin to animals before irradiation lowered total chromosomal aberration from $46 \%$ to $32 \%$.

Pretreatment of buffalo heifers with melatonin reduced the incidence of chromosomal abnormalities and sister chromatid exchange (SCE) during superovulation ( Kandil et al ., 2001 ) .

In bone marrow cell, melatonin caused a decrease in the frequency of chromosomal aberration at a percentage of $7 \%$ via $17 \%$ in diabetic animals . whereas , giving melatonin befor diabetic treatment was more effective than after diabetic occurrence [ Hanafy 2005 ].

Melatonin has been shown to protect DNA from damage inflicted by a physical agent, i .e ., ionizing radiation [Cagnoli et al ., 1995 ] and the bacterial toxin, lipopoly saccharide [ Vijayalaxami et al.,1995 ], both of which are believed to damage the genetic material by free radical mechanisms . Melatonin has been shown to scavenge not only The- oh [ Hayashi et al ., 1992 ], but also possibly the peroxyl radical [ Tan et al .,1993 and Pieri et al., 1994 ] and single oxygen [ Scaiano 1995 ]. Additionally , melatonin seems to increase the concentration of the endogenous antioxidant glutathione and stimulate the antoxidative enzymes superoxide dismutase and glutathione peroxidase [Melchiorri et al., 1995; Sewerynek et al.,1996 and Antolin et al., 1996 ] .

Alower dose chronic treatment of melatonin suggests that the regulation of antioxidant enzymes gene expression is likely to be receptor mediated [ Bhatia and Manada, 2003 and Manada and Bhatia 2004 ] . In conclusion, melatonin produced a significant decrease of the total structural and numerical chromosomal aberration induced by aluminium .

\section{References}

1. Antolin I, Rodriguez C, Sainz R M , Mayo J C, Uria H, Koteer M L , Rodriguez- Colunga M J, Tolivia D and Mendez- pelaez A (1996): Neurohormonal melatonin prevents cell damage: effect on gene expression of antioxidative enzymes . FASEB J. 10 : 882- 890

2. Badr F M, El - Habit $\mathrm{O} \mathbf{H}$ and $\begin{array}{lll}\text { Harraz M } & \text { M (1999) } & \text { : } \\ \text { Radioprotective } & \begin{array}{l}\text { effect } \\ \text { melationin }\end{array} & \text { ofsessed } \\ \text { by }\end{array}$ measuring chromosomal damage in mitotic and meiotic cells . Mutat. Res. 18 ; 444 ( 2 ) : 367 372 .

3. Bhatia $A$ L and Manda $K$ (2003): Melatonin against radiation induced free radicals : a study on tissues of Swiss albino mice .International Association for Radiation Research ,414 :p. p. 343

4. Bock J L and Ash D E ( 1980 ) : 
NMR and infrared spectroscopic investigations of the AL ( III ) Ga ( III ) and Be ( II ) complexes of ATP .J . Inorg. Biochem., 13:105-108.

5. Cagnoli M C, Ataboy C, Kharlamova $\mathbf{E}$ and Manev $\mathrm{H}$ (1995) : Melatonin protects neurons from singlet oxygen -induced apoptosis . J. Pineal Res. $18: 222-226$.

6. Conti A and Maestroni GJM ( 1995 ) : The clinical neuroimmunotherapeutic role of melatonin in oncology . J. Pineal Res.19: 103 - 113 .

7. De-Selvia R, Fiore M, Aglitti T, Festa F, Ricordy $R$ and Cozzi $R$ (1999) : Inhibitory action of melatonin on $\mathrm{H} 2 \mathrm{O} 2$ and cyclophosphamide induced DNA damage. Mutagenesis , 14 ( 1 ): $107-112$

8. Evans EP (1987): karyotyping and sexing of garnets and embryos and fetuses and in situ hybridization to chromosomes. In mammalian development. Apractical approach, Non K, M.(Ed), bl. IRL, Press, Oxford, pp.93:100.

9. Ganrot PO ( 1986 ) : Metabolism and possible health effects of aluminium. Environ. Health Perspect., 65 : 363 -367.

10. Hanafy Z E (2005) : Protective effect of melatonin on mutagenic effects of diabetic male albino rat . African J. Biol. Sci. ,1( 1 ) : 61 68 .

11. Hassan N H ( 1997 ) : Miconazole genotoxicity in Mice. J. Appl. Toxicol. , $17: 313-319$

12. Hayashi M, Kodama Y, Awogi T, Zusuki T, Asita A O, Sofuni T (1992) : The induction of miconucleated polychromatic erythrocytes in mice using single and multiple treatments . Mutat. Res., 278: 209 - 213.

13. Heddle A H, Hite M, Kirkhart B, Mavournin K, MaGregor JT, Newell G W and Salomone M F (1983): The induction of micronucli as a measure of genotoxicity. A report of the U. S. Environment Protection Agency Gene - Tox Program . Mutat. Res ., 123:61-118.

14. Kandil O.M , Mahrous $K$ F and Shalaby S I. (2001) : Effect of pretreatment with melatonin on the ovarian response, hormonal profile, blood biochemical and chromosomal changes in superovulated buffalo heifers .J . Egypt . Vet . Med. Assoc. 61 (2) : 73 84.

15. Kruskal WH and Wallis W A (1952): Use of ranks in once criterion variance analysis, J. Am. Statist Ass., 47,583-621.

16. Lack B, Daya $S$ and Nyokong $T$ (2001) : Interaction of serotoin and melatonin with sodium, potassium ,calcium, lithium and aluminium .J-Pineal .Res ., 31 ( 2 ) : 102 - 108 Lai J C K and Blass J.P ( 1984 ) : Inhibition of brain glycolysis by aluminium. J. Neurochem., 42 : $438-442$

17. Limson $\mathbf{J}$, Nyokong $\mathbf{T}$, and Daya S (1998) :The interaction of melatonin and its precursors with aluminium, cadmium , copper , iron , lead, and zinc : an adsorptive voltammetric study. J-Pineal .Res ., 24 ( 1 ) : $15-21$.

18. Maharaj DS, Molell H, Antunes E M, Maharaj H, Maree D M, Nyokong T, Glass B D and Daya S (2005) : Melatonin generates singlet oxygen on laser irradiation but acts as a quencher when irradiated by lamp photolysis . J.Pineal. Res., 38 ( 3 ) : 153 - 156

19. Manda $K$ and Bhatia $A$ L (2004) : Study on the Antiradiation role of Melatonin : An investigation on Induced Oxidative Stress Mice by Radiomimetice Drug Cyclophosphamide

International Radiation Protection Association 359:p.8

20. Melchiorri D, Reiter R J, Attia A M, Hara M, Burgos $A$ and Nistico C (1995) : Potent protective effect of melatonin on in vivo paraquat induced oxidative damage in rats. Life. Sci. 56 ., $83-89$.

21. Menendez - Pelaez A and Reiter R J (1993) : Distribution of melatonin in mammalian tissues : the relative importance of nuclear versus cytosolic localization, J. Pineal Res., 15 : 59 -69 .

22. Millan-Plano S, Garcia J J, Martinez -Ballarin E, Reiter R J, Ortega-Gutierrez, S, Lazaro R M and Escanero J F (2003) : Melatonin and pinoline prevent 
aluminium - induced lipid peroxidation in rat synaptosomes. J. Trace. Elem . Med. Biol ., 17 ( 1 ) : 39- 44.

23. Muller L and Wilhelm M ( 1987 ) : Uptake and distribution of aluminium in rat hepatocytes and its effect on enzyme lekage and lactate formation. Toxicology , 44 :203-212

24. Nieboer E and Richardson, DH S ( 1980 ) : The replacement of the nondescript term Heay Metals ' by a biologically and chemically significant classification of metl-ions. Environ. Pollut. Ser. B .3

25. Pieri C, Marra M, Moroni F, Recchioni, $\mathbf{R}$ and Mercheselli $\mathbf{F}$ ( 1994 ) : Melatonin : a peroxyl radical scavenger more potent then vitamin E . Life Sci., 55: 271 -276 .

26. Preston $\mathbf{R}$ J, Sebastian $\mathbf{J}$ and McFee A (1987) : The in vitro human lymphocyte assay for assessing the clastogenicity of chemical agents. Mutat. Res.,189: 175 - 179.

27. Regodon S, Martin- Palomino $\mathbf{P}$, Fernandez- Montesinos R, Herrera J L, CarrascosaSalmoral M P, Piriz S, Vadillo S, Guerrero J $M$ and Pozo D (2005) : The use of melatonin as a vaccine agent. Vaccine. $16 ; 23$ ( $46-47$ ) : $5321-5327$.

28. Reiter R J (1991) : Pineal melatonin : cell biology of its synthesis and of its physiological interactions. Endocr. Rev., 12 : $151-180$.

29. Reiter $\mathbf{R}$ J, Melchiorri D, Sewerynek E, Poeggeler B, Barlow - Walden L, Ortiz G G and Acuna - Castroviejo D (1995) : A review of the evidence supporting melatonin $\mathrm{s}$ role as a antioxidant . J. Pineal Res., 18:111 .

30. Riedel B and Christensen G (1979) : Effect of selected water toxicants and chemicals upon adenosine triphosphatase activity in vitro . Bull . Environ . Toxicol ., $23: 365-368$.
31. Scaiano J C (1995) : Exploratory laser flash photolysis study of free radical reactions and magnetic effects in melat-onin chemistry .J. Pineal Res., 19:189195.

32. Sewerynek E, Ortiz GG, Reiter R J, Pablos M I, Melchiorri D and Daniels M WU (1996) : Lipopolysaccharide - induced DNA damage is greatly reduced in rats treated with the pineal hormone melationin .Mol. Cell. Endocrinol., 117 : 183-188.

33. Tan D X, Chen L D, Poeggeler B, Manchester L C and Reiter $\mathbf{R}$ J (1993) : Melationin : a potent endogenous hydroxyl radical scavenger. Endocr. J. 1: 57- 60 .

34. Van -Rensburg S J, Daniels WM, Potocnik F C, Van-Zyl JM, Taljaard $\mathbf{J} \mathbf{J}$ and Emsley $\mathbf{R}$ A (1997): A new model for the pathophysiology of Alzheimer's disease. Aluminium toxicity is exacerbated by hydrogen peroxide and attenuated by an amyloid protein fragment and melatonin .S. Afr. Med . J. , 87 (9 ):1111-1115 .

35. Vijayalaxami $\mathbf{K}$, Reiter $\mathbf{R} \mathbf{J}$, Meltz $M L$ and Herman $T S$ (1998): Melatonin: possible mechanisms involved in its radioprotective effect. Mutat. Res. 404(1-2): 187-189.

36. Vijayalaxami $\mathbf{K}$, Reiter $\mathbf{R} \mathbf{J}$, Sewerynek E, Poeggeler B, Leal B $Z$ and Meltz M L (1995) : Marked reduction of radiation induced micronuclei in human blood lymphocytes pretreated with melatonin. Radiat. Res., 143 : 102- 106 .

37. Vijayalaxmi K, Reiter R J, Tan D x, Herman T S and Thomas C R. (2004): Melatonin as a radioprotective agent : a review . International $\mathbf{J}$. of Radiation Oncology , Bioiogy and Physics ,59(3): 639-65. 
براسة تأثير الميلاتونين على التثوهات الكروموسومية الناتجة من الآثار الضارة للألمونيوم في إناث الجرذ الأبيض

\section{زينب عيد ملبولي حنفي}

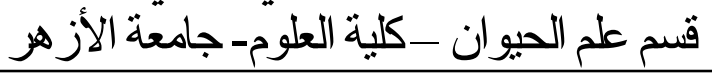

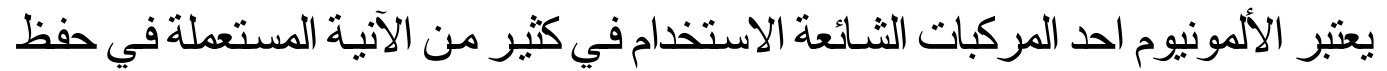

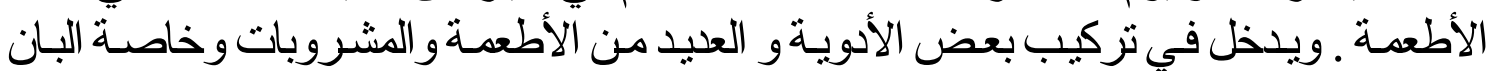

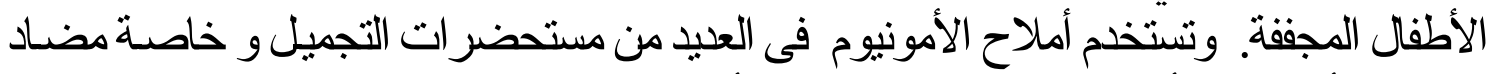

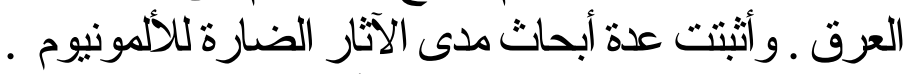

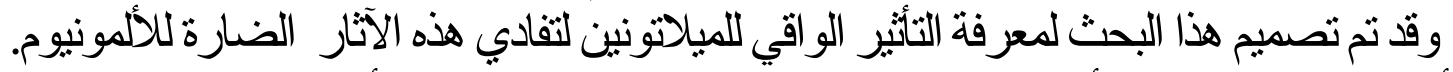

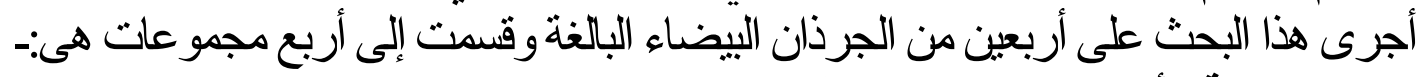

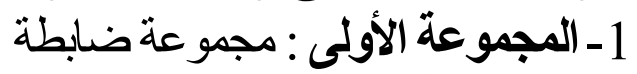

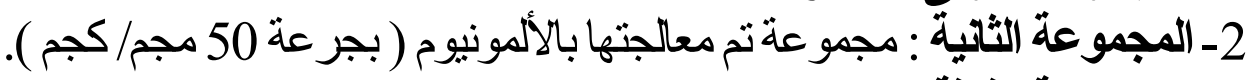

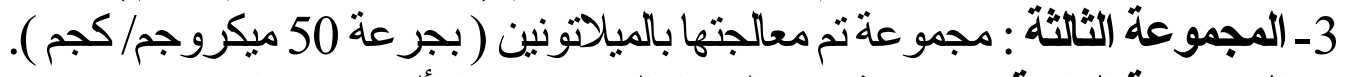

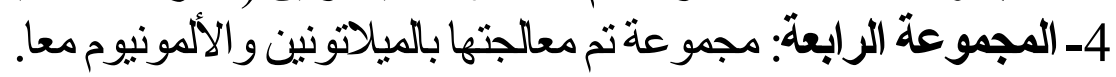

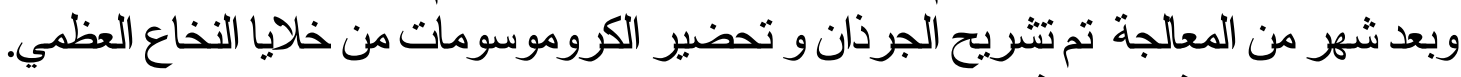

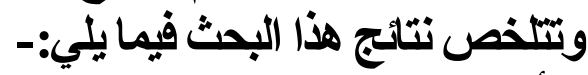

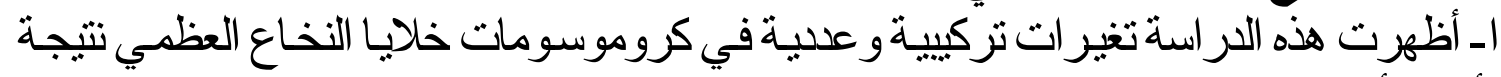

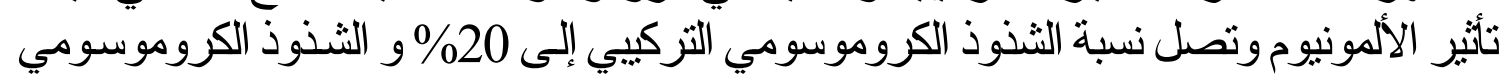
العدي تصل النسبة إلى 11 \% 


\section{Zeinab E.Hanafy}

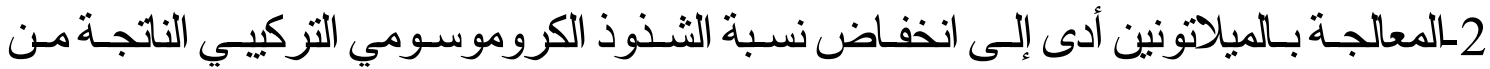

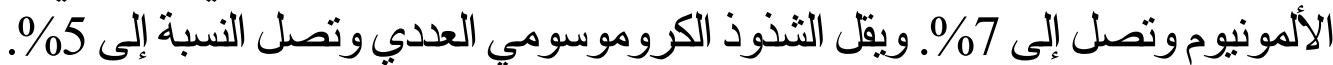

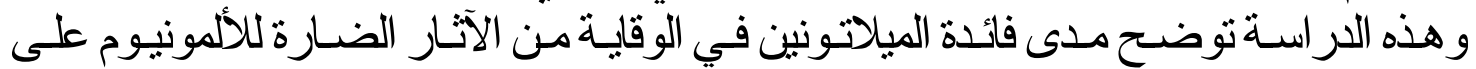

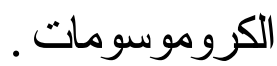

